\title{
Particle-Layer Formation in Aerosol Flow by Simultaneous Deposition and Reentrainment
}

\author{
（微粒子の沈着・再飛散同時現象によるエアロゾル流内粒子層形成）
}

\author{
Woraporn Theerachaisupakij \\ ウォラポン ティラチャイスパキッ
}

\section{Background}

Particle deposition and reentrainment are fundamental phenomena related to numerous engineering applications such as pneumatic transport, dust collection, dry powder coating, particle sampling, atmospheric pollution, and many others. Suspended particles are easily transferred from aerosol flow to a wall by several mechanisms, e.g. inertial effects, turbulent diffusion, Brownian diffusion, gravity settling, thermophoresis and electrostatic effects. In isothermal and electrically neutral system, deposition of sub-micron particles is commonly controlled by a combination of Brownian diffusion and turbulent diffusion, whereas that of micrometer-size particles is remarkably controlled by turbulent diffusion and inertia of particles. If the separation forces acting on the deposited particles are strong enough to overcome the adhesion bonds of particle-particle or particle-surface, the deposited particles are consequently reentrained. Since the deposition, adhesion, and reentrainment are interdependent processes in the formation of particle deposition layer on the wall, it is essential to well characterize and inclusively control them in each system condition.

\section{Introduction}

Over the past few decades, many researchers have paid attention to the deposition and reentrainment. A number of experimental data for deposition rate were summarized in relation to particle relaxation time and flow Reynolds number. Several computer simulations were per-

2002 年 6 月 13 日受付

京都大学大学院工学研究科化学工学専攻

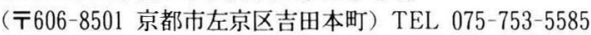

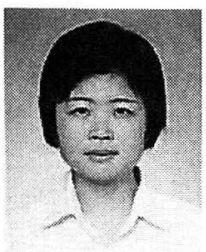

〈著者紹介〉

平成 8 年 3 月チュラロンコーン大学工学部化 学工学科卒業, 平成11年 3 月京都大学大学院 工学研究科化学工学専攻修士課程修了, 平成 14 年 3 月同大学院工学研究科化学工学専攻博 士後期課程修了

専門：エアロゾル，乱流，沈着・最飛散 formed to yield the detailed information on particle motion and deposition mechanism. In general, fine particles deposited on the wall are difficult to be reentrained because of a quite weak drag. Thus, they form particle deposition layer on the wall. Up to the present, the formation of particle deposition layer remains unclear owing to their complexity. Previous investigations have neglected the simultaneous effects of the deposition and the reentrainment. Moreover, the actual state such as the more readily reentrainment of the aggregate from the deposition layer than one of the primary particles has not been considered.

This dissertation, therefore, aims at systematizing the formation characteristics of particle deposition layer on the surfaces and elaborating the mechanism of formation by considering the interdependent processes of deposition, adhesion, and reentrainment. Particular attention was focused on the method to prevent and precisely control the layer formation of adhesive fine particles on the surfaces.

\section{Main Results}

The formation of particle deposition layer in the turbulent aerosol flow resulting from the simultaneous phenomenon of deposition and reentrainment was experimentally, numerically and theoretically investigated and discussed in detail. The results obtained from this study were summarized as follows.

3. 1 Deposition layer of micrometer-size and sub-micron particles

The particle deposition layers formed by alu mina powders (mass median diameter of $0.5-12.5$ $\mu \mathrm{m})$ in the turbulent flow channel were experimentally investigated. Mass of deposited particles per unit wall area was measured with elapsed time and can be expressed as an exponential function for sub-micron particles as well as micrometersize particles. Fig. 1 shows typical patterns of particle deposition layer at equilibrium of deposition and reentrainment. The deposited particles here look white. Filmy deposition layer was observed at a relatively low velocity $(\bar{u}=9.3 \mathrm{~m} / \mathrm{s})$ and striped deposition layer was found as the flow velocity increased $(\bar{u}=15.7 \mathrm{~m} / \mathrm{s})$. At a much 


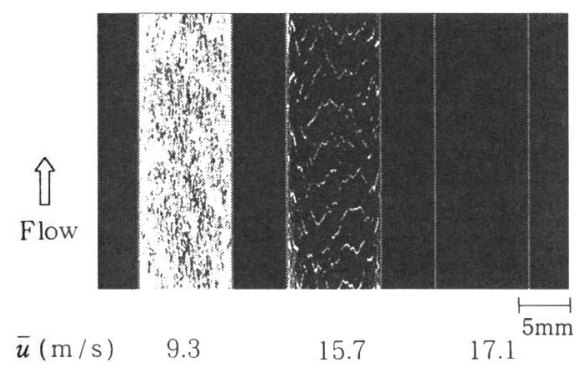

Fig. 1 Photographs of particle deposition layer at different flow velocity $\left(D_{\mathrm{p} 50}=5.6 \mu \mathrm{m}, t=1200 \mathrm{~s}\right)$

higher velocity $(\bar{u}=17.1 \mathrm{~m} / \mathrm{s})$, the critical flow velocity for no particle-layer formation was noticed. While the deposition layar of micrometer-size particles varied from the filmy layer to the striped pattern depending on average flow velocity and particle diameter, for that of sub-micron particles the striped deposition layer was not observed even at flow velocity of $99 \mathrm{~m} / \mathrm{s}$. In comparison with theoretical results, the thickness of particle deposition layer formed on the wall was well explained with the balance of the adhesive strength and the separation strength.

To clarify the reason why an inhomogeneous distribution of deposition occurred in aerosol flow, the particle trajectories and deposition statistics in the neighborhood of the striped deposition layer were numerically investigated. Turbulent flow fields were calculated using the $k-\varepsilon$ model and the Monte Carlo method was applied to simulate the random motion of particles. By an analysis of calculation results, the main factor determining the particle deposition and the features of the particle deposition layer was found to be the inertia of aerosol particles. The hill of striped deposition layer behaved like natural barrier that affected the fluid streamline and the particle motion adjacent to the wall. Interval of the striped deposition layers increased with average flow velocity and particle diameter. These results also imply another important con tribution, i.e., the treatment of surface roughness in striped pattern at intervals smaller than that of the striped deposition layers is effective to prevent the formation of deposition layer.

3. 2 Reentrainment by drag and aerosol collision

Following stated results, the conditions for no particle-layer formation were theoretically and experimentally investigated. Forces and moments acting on the aggregate adhering to the wall, e.g. adhesion force, aerodynamic drag, and collision force, were taken into account at the condition of reentrainment. Analytical results showed that the collision force plays an important role in the reentrainment for aerosol particles of several micrometers, and the effect of aerodynamic drag became more prominent for smaller particles. The critical flow velocity for no particle-layer formation decreased as the diameter of aerosol particles increased. To confirm the theoretical

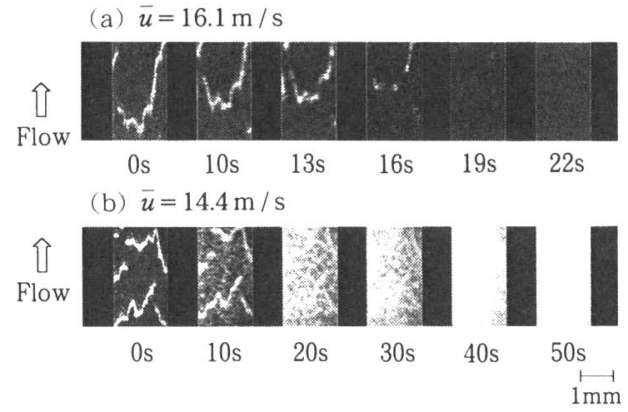

Fig. 2 Photographs of particle deposition layer on vibrating wall $\left(D_{\mathrm{p} 50}=5.0 \mu \mathrm{m}\right)$

analysis, the measurements of critical flow velocity for no particle-layer formation were conducted using alumina particles of size $3.3-10.3 \mu \mathrm{m}$ in mass median diameter. Experimental results were in good agreement with the theoretical ones. Larger aerosol particles formed the particle deposition layer at lower velocity and the critical flow velocity required to remove the deposition layer by airflow was much higher than that by aerosol flow. The enhancement in removing the deposited particles using larger aerosol particles was confirmed. These results can be applied for the cleaning technique, for example, to remove the highly adhesive particles from flow channel.

3. 3 Effect of wall vibration on the formation of particle deposition layer

According to the moment balance, an external force, e.g. vibration force, was applied to enhance the particle reentrainment. The formation of particle deposition layer on the vibrating wall was observed with respect to elapsed time and the wall vibration was analyzed using a laser Doppler method. Fig. 2 shows the transition states of particle deposition layer after starting the wall vibration $1070 \mathrm{~m} / \mathrm{s}^{2}$. For $\bar{u}=16.1 \mathrm{~m} / \mathrm{s}$, the amount of deposited particles decreased and ultimately they disappeared from the wall (see Fig. 2a). The wall vibration enhanced the particle reentrainment. However, for $\bar{u}=14.4 \mathrm{~m} / \mathrm{s}$ the amount of deposited particles increased with wall vibration (see Fig. 2b). A new filmy deposition layer was formed over the striped deposition layer. These results indicated that the wall vibration plays two opposite roles, i.e., (i) to increase the separation force and (ii) to increase the particle deposition rate due to active capture of aerosol particles.

In addition, the critical flow velocity for no particle-layer formation under various vibration accelerations was experimentally notified and compared with theoretical results. The critical flow velocity decreased with increasing vibration acceleration and particle diameter. These results were well explained by the moment balance model.

\section{Acknowledgements}

The author is deeply indebted to Professor Hiroaki Masuda and Associate Professor Shuji Matsusaka.

(Ph. D. awarded in March 2002, Kyoto University) 